\title{
References:
}

1. Popovych A. S. (2017) Lingvoekolohichnyi pryntsyp navchannia stilystyky maibutnikh uchyteliv ukrainskoi movy i literatury [Lingual-ecological principle of teaching the style of future teachers of Ukrainian language and literature]. Scientific Bulletin of Mykolaiv National University named after Sukhomlinsky. Pedagogical science., 3 (58).

2. Chernilevskyi D. V. Tomchuk M. I., Dubaseniuk O. A., Antonova O. Ye. Zakharchenko V. I., Vozniuk O. V., Siranchuk N. Z. (2017) Metodolohiia naukovoi diialnosti [Metodologic of scientific activity] Vinnytsia. Naland-LTD. [in Ukrainiane].

3. Haugen E. (2006). The Ecology of Language. The Ecolinguistics Reader: Language, Ecology and Environment. A. Fill, P. Muhlhausler (Eds). Continuum international publishing group, 57-66. Retrieved from: www.books.google.com.ua.

\section{Ponomarenko N. P. Speech competence developing model of the junior specialists in journalism within professional} training process

One of the most important element of competency training for students of specialty 061 «Journalism» (Specialization «Publishing and Editing») in higher education institutions I-II accreditation level is the developing of speech competence.

The complex of research methods was used in the study: theoretical: analysis, synthesis, systematization, which made it possible to formulate the initial assumptions of the study, to determine the state of development of the identified problem, modeling method for developing and substantiation of the model of junior specialists speech competence during training. Empirical methods, such as generalization of pedagogical experience, analysis of programs, results of educational, practical, scientific work of students to study the current state of speech competence of future junior specialists in journalism.

Modeling the speech competence of future junior journalists in the field of professional training is a purposeful, organized, holistic process aimed at updating motivation for the formation of language skills, gaining personal experience in the implementation of various types of speech activities. These principles ensure the design of the educational process based on a systematic model of learning and provide for the formation of speech competence. The implementation of the content block of the structural and functional model contributes to enriching and updating the system of modern Ukrainian literary language knowledge, taking into consideration the modern labor market; modern educational technologies introduction into the educational process, ensuring psychological interaction of participants in the educational process. The technological block of the model projects the implementation of the content block and aims at developing speech skills. The result block of the model allows to determine the level of dynamics of speech competence formation, which is a testament to the professional development of future junior specialists in journalism.

More detailed experimental verification of the components readiness will be described in the following publications.

Key words: model, modeling, speech competence, development of speech competence, junior specialist of specialty 061 «Journalism», blocks of speech competence developing model of future junior specialists in journalism, content block, result block, technology block.

УДК 37.014.5 (015.3) / 377:159.992 (477)

DOI https://doi.org/10.31392/2311-5491/2019-70.49

Постоян Т. Г., Новітська І. В.

\section{ДОСЛІДЖЕННЯ СТАНУ ПОПЕРЕДЖЕННЯ ТА ПРОТИДІЇ БУЛІНГУ В УМОВАХ ЗАКЛАДУ ОСВІТИ: ПРАКТИЧНИЙ АСПЕКТ}

\begin{abstract}
Формування безпечного освітнього середовища в закладі освіти є однією з важсливх умов досягнення високого рівня результату навчання. Поширення насильства в закладах освіти підтверджується соиіологічними дослідженнями та місиями України в першій десятиі в рейтингу за кількістю жертв булінгу. Правова безпорадність здобувачів освіти, низька конфліктологічна компетентність, неготовність закладів освіти оприлюднювати факти булінгу роблять неефективною наявну систему захисту прав учасників освітнього процесу.

Мета статті - представити результати дослідження стану управління системою попередження та протидіi булінгу в закладі освіти на прикладі Економіко-правового коледжу Міжнародного гуманітарного університету (місто Одеса). Завдання дослідження - визначити обізнаність студентів щуодо булінгу як соціального явища; встановити факт участі в булінгу, роль учасника булінгу; визначити стан сочіально-правової системи попередження та протидї булінгу в коледжі. У результаті дослідження визначено найбільш поширені форми булінгу - психологічне насильство: образливі прізвиська, плітки, приниження, бойкот. Встановлено, шо булінг спостерігається в різних групах, незалежно від курсу, найчастіше - в Інтернеті та на шляху до коледжу або з нього. До найбільш характерних рис жертв булінгу студенти віднесли фізичну слабкість, матеріальне становище, зовнішність студента. Визначено недостатню активність педагогів у протидї булінгу. Дійшли висновку, щзо зміст і форми роботи адміністрації коледжу шзодо попередження та протидї булінгу недостатньо ефективні та потребують перегляду для посилення відповідальності за дотримання чинного антибулінгового законодавства Украӥни всіма учасниками освітнього процесу та створення безпечного освітнього середовища, вільного від булінгу.
\end{abstract}

Ключові слова: заклад освіти, освітнє середовище, безпека, булінг, попередження, протидія, анкетування, результати.

Сучасний етап розвитку вищої освіти в Україні пов’язаний із широким упровадженням системи управління якістю освіти, яка покликана забезпечити високий рівень якості знань здобувачів вищої освіти з орієнтацію на задоволення потреб стейкхолдерів і роботодавців. Це потребує певних зусиль щодо формуванням 
безпечного освітнього середовища, сприяння зниженню соціальної напруги, однією із причин якої є булінг. На жаль, здобувачі освіти в освітньому середовищі закладу стикаються із проявами нетерпимості, агресії, дискримінації, психологічного та фізичного насильства - булінгом, що є проблемою для сучасної освіти України, адже булінг є загрозою для духовного, морального та професійного становлення особистості як члена суспільства. Попередження та подолання булінгу забезпечує досягнення соціальної стабільності, високої якості професійної підготовки майбутніх фахівців в умовах закладу освіти і в системі освіти України загалом.

Поширення насильства в закладах освіти підтверджується соціологічними дослідженнями, проведеними в Україні. За даними дослідження Всесвітньої організації охорони здоров'я (далі - ВООЗ), яке проводилось у 2013-2014 рр., Україна посіла 9-те місце серед 42 досліджуваних країн за кількістю жертв булінгу. У лютому 2017 р. UNICEF, розпочавши роботу проти цькування, провело дослідження серед підлітків віком 11-17 років по всій Україні. За результатами цього дослідження 67\% підлітків в Україні віком від 11 до 17 років стикалися із проблемою булінгу протягом останніх трьох місяців, з них 48\% нікому не розповідали про ці випадки [6].

За результатами дослідження Д. Марцинковського, $80 \%$ дітей до 15-тирічного віку в Україні стикаються iз проявами булінгу як спостерігачі, жертви або ініціатори. Приблизно 8\% є постійними жертвами, яких цькують декілька разів на тиждень [11].

Наведені результати свідчать про те, що заклади освіти є одним із місць, де діти досить часто стикаються 3 насильством. Такі невтішні результати досліджень і перебування України на перших місцях рейтингу за кількістю жертв булінгу свідчать про те, що ця проблема потребує негайного правового регулювання, а система міжнародно-правових актів у сфері захисту прав дитини від усіх форм насильства, в освітньому середовищі також, ратифікованих Україною, - імплементації до національного законодавства.

Міністерство освіти і науки (далі - МОН) України (2018р.) розробило «Методичні рекомендації щодо запобігання та протидії насильству» [4]. Наступним кроком стало ухвалення у грудні 2018 р. Верховною Радою України Закону України «Про внесення змін до деяких законодавчих актів України щодо протидії булінгу (цькуванню)» № 2657-VIII, у якому термін «булінг» визначено як «діяння учасників освітнього процесу, які полягають у психологічному, фізичному, економічному, сексуальному насильстві, у тому числі iз застосуванням засобів електронних комунікацій, що вчиняються стосовно малолітньої чи неповнолітньої особи або такою особою стосовно інших учасників освітнього процесу, внаслідок чого могла бути чи була заподіяна шкода психічному або фізичному здоров'ю потерпілого» [1]. Законом окреслено шляхи попередження та протидії булінгу, внесено зміни до Кодексу України про адміністративні правопорушення та Закону України «Про освіту».

Водночас розроблено «Рекомендації Міністерства освіти і науки України для закладів освіти щодо застосування норм Закону України «Про внесення змін до деяких законодавчих актів України щодо протидії булінгу (цькуванню)»« на доповнення листа від 29 грудня 2018 р. № 1/9-790 [3].

На жаль, правова безпорадність громадян України, необізнаність як дорослих, так і дітей, низька конфліктологічна компетентність керівників та педагогічних працівників закладів освіти, неготовність закладів освіти оприлюднювати факти вчинення булінгу роблять неефективною наявну систему захисту прав дітей. Тому проблема булінгу залишається актуальною та потребує систематичного вивчення.

Різні аспекти булінгу як соціального явища досліджували закордонні та вітчизняні вчені, серед яких: Д. Олвеус, А. Пікасо, Е. Роланд, П. Хайнеман, Р. Каталано, Л. Хоукінс, Д. Лейн, Е. Мунте, Д. Таттум, І. Бердишев, I. Кон, І. Ачитаєва, В. Вишневська, Д. Кутузова, А. Стрельбицька, Е. Файнштейн, М. Дмитренко, О. Лавриненко, Л. Лушпай, О. Ожийова й інші.

За Д. Ольвеусом, булінг - це умисна, систематично повторювана й агресивна поведінка, що включає нерівність соціальної влади або фізичної сили. Вчений виділив основні риси булінгу: систематичність; нерівність фізичних і соціальних можливостей у відносинах між жертвою й агресором, відсносини переслідувача і жертви, та запропонував модель дослідження булінгу в освітньому середовищі, що стало засадничим механізмом для подальшого вивчення проблеми [13].

I. Бердишев досліджував психологічні аспекти булінгу та девіантної поведінки дітей і підлітків в освітньому середовищі. Вчений під булінгом розуміє свідоме, тривале насильство, що не має характеру самозахисту і походить від одного або декількох людей [5].

О. Ожийова досліджувала соціолого-правові й управлінські аспекти проблеми булінгу. Дослідниця визначає булінг як «<..> навмисне, таке, що не має характеру самозахисту та не санкціоноване нормативно-правовими актами держави, тривале (повторне) фізичне або психічне насилля з боку індивіда або групи, які мають визначені переваги (фізичні, психологічні, адміністративні тощо), щодо індивіда, і яке відбувається в організованих колективах із визначеною метою (наприклад, бажання здобути авторитет у певних осіб)» $[7$, с. 76].

В українських словниках тлумачення терміна «булінг» немає, однак пояснюються спорідненні поняття, зокрема: насильство - застосування силових методів або психологічного тиску за допомогою погроз, свідомо спрямованих на слабких або тих, хто не може чинити опір; панування, влада людини над людиною; агресія - дії, спрямовані на порушення фізичної і психічної цілісності людини або групи людей [12]. Агресія, хоча й пов'язана з насильством, проте ширше за поняття насильства і охоплює його. До поняття агре- 
сії також входить третирування (прояв зневаги до когось, безцеремонне поводження, нехтування чужої думки [9, с. 248]) та цькування (переслідування кого-небудь різними нападками, наклепами тощо, знущання 3 когось [10, с. 259]). Усі ці поняття окреслюють різні прояви явища «булінг».

Мета статті - представити результати дослідження стану управління системою попередження та протидії булінгу в Економіко-правовому коледжі Міжнародного гуманітарного університету (м. Одеса).

Згідно зі змінами, внесеними до ст. 26 Закону України «Про освіту», на керівників закладів освіти покладено обов'язок щодо створення в закладах освіти безпечного освітнього середовища, зокрема розробка, затвердження й оприлюднення плану заходів, спрямованих на запобігання та протидію булінгу в закладі освіти. Закон також зобов'язує педагогічних працівників повідомляти керівників закладів освіти про виявлені факти булінгу [2].

3 метою визначення стану управління попередженням і протидією булінгу в закладах освіти, відповідно до національного законодавства України, на базі Економіко-правового коледжу Міжнародного гуманітарного університету (м. Одеса) проведено дослідження, яке дало змогу визначити рівень обізнаності колективу із проблеми булінгу та сформованості соціально-правової системи попередження та протидії булінгу в закладі освіти.

Економіко-правовий коледж Міжнародного гуманітарного університету, заклад освіти приватної форми власності, здійснює підготовку фахівців за спеціальностями: 081 «Право», 051 «Економіка», 123 »Комп'ютерна інженерія».

Дослідження проводилось серед студентів першого курсу денної форми навчання в кількості 66 осіб, оскільки саме ці студенти будують міжособистісні відносини, намагаються самоствердитися в новому освітньому середовищі та новому колі спілкування, що спричинює булінг і потребує моніторингу цієї категорії студентів із метою попередження та протидії булінгу в закладі освіти.

Методами дослідження виступили: спостереження, індивідуальні бесіди, анкетування.

3 метою визначення рівня обізнаності студентів щодо проблеми булінгу як суспільного явища використано анкетування. Серед опитаних респондентів 84\% (52) - це дівчата, а 16\% (14) - хлопці. Студенти коледжу мають різні етнокультурні (мовні, релігійні) відмінності: більшість 3 опитаних українці, є болгари, молдовани, росіяни, євреї й азербайджанці. Студенти належать до різних соціально-демографічних груп населення, зокрема: $63 \%$ опитаних є місцевими мешканцями, 37\% приїхали з Одеської й інших областей України. Вік опитаних - від 16 до 17 років. Освіту здобувають студенти із сімей із різними статками, що зумовило економічну нерівність серед студентів.

З урахуванням того, що в дослідженні брали участь студенти першого курсу, для анкетування були обрані педагоги, які викладають на першому курсі та $є$ кураторами студентських груп (18 викладачів).

Викладачі у встановлений законодавством термін (раз на 5 років) підтверджували або підвищували категорію, проте ніхто з них не підвищував кваліфікацію із проблеми попередження та протидії булінгу.

На основі опитувальника OLWEUS [8] для анкетування розроблено зміст анкети для студентів, завдання якої полягали у визначенні обізнаності студентів щодо булінгу як соціального явища; встановлення можливості участі в булінгу, ролі учасника (жертва/нападник); визначення стану соціально-правової системи попередження та протидії булінгу, захисту від нього в коледжі. Обізнаність щодо булінгу як соціального явища визначалася за допомогою таких питань: «Чи знаєш ти, що таке булінг?», «Чи розумієш ти зміст визначення: «Насиллям є будь-яка дія однієї людини щодо іншої, унаслідок чого завдається психічна або фізична шкода здоров'ю? Чи погоджуєшся 3 ним?».

Питання «Чи доводилося особисто тобі пережити булінг у коледжі?», «Які саме дії вчинялися щодо тебе?» спрямовані на виявлення жертв знущань, встановлення фактів знущань у коледжі та їхні найпоширеніші форми.

Для визначення осередку знущань у колі студентів в анкеті було питання щодо того, де вчиняється насильство: у студентській групі, на старших курсах чи деінде.

3 метою визначення місць, які потенційно можуть бути небезпечними та сприятливими для вчинення булінгу, в анкеті було питання про те, де найчастіше вчиняються знущання: на спортивному майданчику, у коридорах, на сходах, в Інтернеті, в аудиторії (за присутності чи відсутності викладача), у туалеті, спортзалі, їдальні, на шляху до коледжу або з нього, на зупинці транспорту або в інших місцях.

3 метою визначення загальних рис потенційних жертв булінгу, які, на думку студентів, є визначальною причиною цькування, в анкеті представлено такі характеристики: фізична слабкість, відмінність у статках, зовнішня непривабливість, незалежність думки.

3 метою виявлення ставлення студентів до вчинення булінгу над іншими студентам було запропоновано обрати варіанти відповіді: співчуваю жертві та прагну допомогти; співчуваю певною мірою; не співчуваю та вважаю, що жертви на це заслуговують.

На визначення, наскільки активною є участь викладачів і кураторів студентських груп щодо попередження булінгу та встановлення факту знущань за присутності чи відсутності викладача спрямовані такі питання анкети: «Чи втручаються викладачі, щоб зупинити булінг?», «Чи впливає куратор на припинення булінгу у групі?», «До кого ти чи твої друзі можуть звернутися по допомогу, щоб захиститися від булінгу в коледжі?». 
На визначення захищеності студентів коледжу спрямовані питання: «Чи є актуальною проблема булінгу для коледжу?», «Чи лякає тебе ймовірність булінгу з боку інших студентів?», «Чи можеш ти дозволити собі висловити власну думку у присутності викладача?», «Чи виникали ситуації булінгу викладачів щодо студентів?», «Чи гарантує коледж дотримання прав студентів?», «Чи втручаються студенти, щоб зупинити булінг стосовно інших?», «Чи можеш ти приєднатися до булінгу щодо студента, який тобі не подобається?».

Завданнями анкетування викладачів було: визначити рівень їхньої поінформованості щодо чинних норм законодавства України, обізнаності щодо їхніх прав і обов'язків у протидії булінгу; встановити випадки булінгу в коледжі, наявність системи попередження та протидії булінгу. Відповідно до завдань сформульовані такі питання: чи знайомі педагоги з антибулінговим законодавством та мірою відповідальності за вчинення та/або неповідомлення про факти здійснення булінгу (права й обов'язки у випадках булінгу)? Чи проводиться у коледжі інформаційна робота щодо попередження та протидії булінгу? Чи отримували педагоги інструкції від адміністрації щодо запобігання та попередження булінгу? Чи стикалися вони з випадками булінгу серед студентів, на що потрібно звертати увагу для його виявлення? Які заходи вживають куратори для попередження булінгу? Чи розроблено та доведено загальний план заходів із попередження булінгу в коледжі?

Узагальнені результати анкетування студентів із метою визначення стану попередження та протидії булінгу представлено в таблиці 1.

Таблиця 1

Результати анкетування студентів із метою визначення стану попередження та протидії булінгу

\begin{tabular}{|c|c|c|c|}
\hline \multirow{2}{*}{ Питання анкети } & \multicolumn{3}{|c|}{ Відповіді, \% } \\
\hline & так & ні & немає \\
\hline Чи знаєш ти, що таке булінг? & 86 & 14 & 0 \\
\hline Чи доводилося особисто тобі пережити булінг у коледжі? & 14 & 86 & 0 \\
\hline Чи втручаються викладачі, щоб зупинити булінг щодо студентів? & 71 & 23 & 6 \\
\hline Чи впливає куратор на припинення булінгу у групі? & 24 & 56 & 20 \\
\hline Чи втручаються студенти, щоб зупинити булінг стосовно інших? & 83 & 15 & 2 \\
\hline Чи співчуваєш ти жертвам булінгу, чи прагнеш допомогти? & 76 & 21 & 3 \\
\hline Чи можеш ти приєднатися до булінгу стосовно студента, який тобі не подобається? & 18 & 74 & 8 \\
\hline Чи лякає тебе ймовірність булінгу з боку інших студентів? & 42 & 58 & 0 \\
\hline Чи виникали ситуації булінгу викладачів щодо студентів? & 65 & 35 & 0 \\
\hline Чи дозволяють студентам висловити власну думку у присутності викладача? & 86 & 14 & 0 \\
\hline $\begin{array}{l}\text { Чи можуть студенти звернутися по допомогу до викладачів або адміністрації коледжу } \\
\text { в разі факту булінгу? }\end{array}$ & 26 & 68 & 6 \\
\hline Чи актуальна проблема булінгу для коледжу? & 32 & 48 & 20 \\
\hline $\begin{array}{l}\text { Чи проводиться в коледжі роз'яснювальна робота щодо попередження булінгу, } \\
\text { до кого звертатися? }\end{array}$ & 23 & 56 & 21 \\
\hline Чи гарантує коледж дотримання прав студентів? & 30 & 70 & 0 \\
\hline
\end{tabular}

Результати таблиці засвідчують, що обізнаними щодо булінгу вважають себе $86 \%$ студентів, $84 \%$ з яких складають дівчата і $16 \%$ - хлопці. Дівчата мають більш чітке уявлення про булінг як соціальне явище, надали його визначення, найбільш наближене до законодавчого.

Відповіді на питання анкети дали змогу виявити, наскільки проблема булінгу актуальна для коледжу, які його форми найбільш поширені в освітньому середовищі закладу освіти. 3'ясовано, що жертвами булінгу вважають себе 14\% (9 студентів), серед них 8 дівчат і 1 хлопець. Найпоширенішими формами булінгу більшість студентів визначили види психологічного насильства, а саме: образливі прізвиська, плітки, приниження, бойкот. Один респондент визначив пошкодження речей як прояв фізичного насильства, один респондент визначив факт вимагання грошей.

За результатами відповідей респондентів встановлено, що випадки булінгу трапляються в різних групах незалежно від курсу.

Серед місць, які є потенційно небезпечними та сприятливими для вчинення булінгу, студенти здебільшого назвали Інтернет, на шляху до коледжу або з нього, менше - на території коледжу (аудиторія за відсутності викладача, їдальня, спортивний зал).

Жертвою булінгу може стати будь-який студент, але для розробки дієвих заходів профілактики булінгу потрібно розуміти загальні характеристики потенційних жертв булінгу, які, на думку студентів, спричинюють це явище. Найбільш характерними рисами жертв насилля респонденти визначили фізичну слабкість (17\%), відмінність у статках (8\%), зовнішню непривабливість (18\%), незалежність думки (12\%). 39\% респондентів уважають визначальними всі представлені характеристики. Респонденти визначили власні причини булінгу. Так, на думку $3 \%$ респондентів, жертвами булінгу є морально нестійкі студенти. $3 \%$ опитаних не визначились із відповіддю. 
Щоб зрозуміти, наскільки активною є участь викладачів у протидії булінгу в коледжі, студенти відповідали на питання анкети «Чи втручаються викладачі, щоб зупинити булінг стосовно студентів?». Серед опитаних $33 \%$ студентів обрали варіанти відповідей «часто або майже завжди», 38\% - «іноді або рідко», 23\% - «майже ніколи», 6\% студентів утрималися від відповіді. Отже, участь викладачів у протидії булінгу в коледжі є недостатньою, переважно діє «політика невтручання» у випадках знущання одних студентів над іншими.

Що стосується впливу куратора на припинення булінгу у групі, то 56\% респондентів уважають, що куратор не впливає або майже не впливає на такі ситуації, 18\% респондентів зазначили, що куратор має незначний вплив, лише $24 \%$ опитаних уважають, що куратор суттєво впливає на припинення булінгу у групі. Такі відповіді пояснюються тим, що респонденти - представники різних груп.

Відповіді на питання: «Чи втручаються студенти, щоб зупинити булінг стосовно інших?» розподілились так: $36 \%$ респондентів уважають, що студенти намагаються допомогти, 47\% відповіли, що студенти втручаються зрідка, а $15 \%$ респондентів обрали «майже ніколи».

Серед респондентів співчувають жертвам і прагнуть допомогти 44\%, 32\% співчувають деякою мірою, а $21 \%$ респондентів не співчувають і вважають, що жертви на те заслуговують.

Отже, майже половина студентів виявляють негативне ставлення до булінгу, захищають жертву або намагаються їй допомогти, третина негативно ставляться до насилля, проте нічого не роблять, а $21 \%$ опитаних байдуже ставляться до факту булінгу.

На питання анкети: «Чи можеш ти приєднатися до булінгу щодо студента, який тобі не подобається?», $74 \%$ респондентів відповіли, що не стануть цього робити, 12\% респондентів відповіли, що така ситуація можлива, 6\% - «так», а 8\% респондентів не визначились із відповіддю. Отже, 18\% респондентів можна віднести до потенційних булерів, яким подобаються знущання, але вони приховують це.

Результати відповідей респондентів щодо ймовірності булінгу в коледжі розподілилися так: 64\% хлопців виключають таку ймовірність, 29\% така ймовірність лякає зрідка, а 7\% - дуже часто. Що стосується дівчат, то 56\% із них заперечують можливість знущання над ними, 34\% зрідка побоюються можливості булінгу, а $10 \%$ часто очікують такої ситуації. Отже, $42 \%$ серед опитаних студентів допускають можливість булінгу щодо себе з боку інших студентів, найуразливішими в коледжі себе вважають дівчата.

3 випадками знущань із боку викладачів стикалися $65 \%$ респондентів, водночас $86 \%$ респондентів дозволяють собі висловити власну, незалежну думку у присутності викладачів.

Отже, існує наявна проблема в міжособистісних стосунках учасників освітнього процесу в коледжі, яку потрібно вирішувати, починаючи передусім із педагогічного складу колективу коледжу.

На питання анкети «До кого ти чи твої друзі можуть звернутися по допомогу, щоб захиститися від булінгу в коледжі?», 26\% респондентів відповіли, що можуть звернутися до викладачів або адміністрації коледжу, $53 \%$ - до друзів або батьків, 14\% - ні до кого, а $6 \%$ не стикались із цією проблемою. Один респондент (дівчина) відповів, що в такій ситуації треба звертатися до поліції. Актуальною проблему булінгу для коледжу вважають $32 \%$ респондентів, не визначилися - $20 \%$, не бачать у цьому проблеми - $48 \%$.

На питання щодо того, чи розповідали студентам коледжу, як попередити булінг і до кого звертатися, $23 \%$ респондентів відповіли, що з ними проводилась інформаційна робота щодо протидії булінгу; $56 \%$ відповіли, що ні, а $21 \%$ респондентів не відповіли на питання.

Що стосується гарантування коледжем прав студентів, то 30\% респондентів відповіли позитивно, 14\% відповіли, що на їхні права в коледжі не зважають, а 56\% респондентів уважають, що це відбувається не завжди.

Узагальнені результати анкетування викладачів із метою визначення стану попередження та протидії булінгу представлено в таблиці 2.

Таблиця 2

Результати анкетування викладачів із метою визначення стану попередження та протидії булінгу

\begin{tabular}{|c|c|c|c|c|c|c|}
\hline \multirow{2}{*}{ Питання } & \multicolumn{2}{|c|}{ так } & \multicolumn{2}{|c|}{ ні } & \multicolumn{2}{|c|}{ не знаю } \\
\hline & викл. & $\%$ & викл. & $\%$ & викл. & $\%$ \\
\hline Ви обізнані щодо законодавства про булінг? & 18 & 100 & 0 & 0 & 0 & 0 \\
\hline Ви обізнані із правами й обов'язками для протидії булінгу в коледжі? & 17 & 94 & 1 & 6 & 0 & 0 \\
\hline Ви стикалися з випадками булінгу серед студентів коледжу? & 8 & 44 & 10 & 56 & 0 & 0 \\
\hline $\begin{array}{l}\text { Ви ознайомлені із планом заходів, спрямованих на попередження } \\
\text { та протидію булінгу в коледжі? }\end{array}$ & 10 & 56 & 0 & 0 & 8 & 44 \\
\hline $\begin{array}{l}\text { Ви отримали інструкції від адміністрації закладу щодо попередження } \\
\text { та протидії булінгу в коледжі? }\end{array}$ & 15 & 83 & 0 & 0 & 3 & 17 \\
\hline
\end{tabular}

За результатами анкетування викладачів, представленими в таблиці, щодо їхньої обізнаності із законодавством України про булінг і мірою відповідальності за вчинення булінгу та/або неповідомлення про факти його здійснення, обізнаними вважають себе всі респонденти, один респондент відповів, що не знає своїх обов’язків і правил поведінки, якщо став свідком булінгу або отримав інформацію про його вчинення. 
Щодо того, чи стикалися викладачі з випадками булінгу серед студентів коледжу, 44\% респондентів відповіли «так», $56 \%$ - «ні» .

$35 \%$ респондентів уважають інформаційну роботу, що проводиться в коледжі, недостатньою. На питання, чи розроблено та доведено до відома всіх учасників освітнього процесу план заходів, спрямованих на запобігання булінгу в коледжі, $56 \%$ респондентів відповіли «так», проте $44 \%$ не змогли визначитись із відповіддю. Водночас $17 \%$ респондентів не дали відповіді на питання «Ви отримали інструкції від адміністрації закладу щодо попередження та протидії булінгу в коледжі?».

Для встановлення щирості у відповідях та визначення реального стану соціально-правової системи захисту проти булінгу в коледжі було закладено єдину змістову сутність у питаннях: «Ви ознайомлені із планом заходів, спрямованих на попередження та протидію булінгу в коледжі?» та «Ви отримали інструкції від адміністрації закладу щодо попередження та протидії боулінгу в коледжі?». Суперечливі відповіді на типові запитання засвідчили або нещирість у відповідях, пов'язану з острахом щодо погіршення стосунків із керівництвом за «надмірну відвертість», або некомпетентність у проблемі булінгу.

На питання «На що треба звертати увагу для виявлення булінгу на його ранніх стадіях?» 35\% респондентів зазначили спілкування між студентами, особливо на перервах; $24 \%$ респондентів визначили, що на дратівливість і нецензурну лайку; 30\% - на зміну стосунків між студентами; $11 \%$ - на невмотивовану агресію.

Аналіз відповідей респондентів щодо заходів, які проводять куратори у групах для попередження булінгу, показав, що 83\% педагогів дали схожі відповіді, а саме: проведення тематичних бесід, круглих столів, відеопрезентації в межах виховних годин. 17\% педагогів поза межами спільних виховних годин додатково практикують відверте індивідуальне спілкування зі студентами.

Висновки. За результатами дослідження стану системи попередження та протидії булінгу в закладі освіти на прикладі Економіко-правового коледжу Міжнародного гуманітарного університету (м. Одеса) 3'ясовано, що більшість викладачів і студентів або ігнорують факти булінгу, або не готові надати допомогу через необізнаність і некомпетентність. Наявний стан попередження та протидії булінгу в коледжі не викликає у студентів належної довіри, що є наслідком недієвості механізмів попередження та протидії булінгу. Недостатня протидія булінгу з боку викладачів і студентів не зупиняє булінг та не формує почуття захищеності в освітньому середовищі коледжу. Наявні методи профілактичної й інформаційної роботи щодо попередження та протидії булінгу малоефективні та потребують перегляду з боку адміністрації коледжу, яка несе відповідальність за дотримання чинного антибулінгового законодавства України всіма учасниками освітнього процесу та створення безпечного освітнього середовища, вільного від булінгу.

\section{Використана література:}

1. Про внесення змін до деяких законодавчих актів України щодо протидії булінгу : Закон України від 18 грудня 2018 р. № 2657-VIII / Верховна Рада України. URL: https://zakon.rada.gov.ua/laws/show/2657-19 (дата звернення: 19.09.2019).

2. Про освіту : Закон України від 5 вересня 2017 р. № 2145-VIII / Верховна Рада України. URL: https://zakon.rada.gov.ua/ laws/show/2145-19 (дата звернення: 19.09.2019).

3. Рекомендації МОН України для закладів освіти щодо застосування норм Закону України «Про внесення змін до деяких законодавчих актів України щодо протидії булінгу (цькуванню)» від 29 грудня 2018 р. № 1/9-790. URL: https://don.kyivcity.gov.ua/files/2019/2/14/buling.pdf (дата звернення: 19.09.2019).

4. Методичні рекомендації щодо запобігання та протидії насильству : лист МОН України № 1/11-5480 від 18 травня 2018 p. URL: https://zakon.rada.gov.ua/rada/show/v5480729-18 (дата звернення: 12.09.2019).

5. Бердышев И. Медико-психологические последствия жестокого обращения в детской среде. Bonpocbl диагностики и профилактики : практическое пособие / под ред. Л. Рубинной. Санкт-Петербург, 2005. 51 с.

6. Булінг - важлива проблема для дітей в Україні. ЮНІСЕФ розпочинає кампанію проти булінгу. Педагогічний портал : освітня преса. URL: http://pedpresa.ua/185372-buling-vazhlyva-problema-dlya-ditej-v-ukrayini-yunisefrozpochynayekampaniyu-proty-bulingu.html (дата звернення: 19.09.2019).

7. Ожиёва Е. Буллинг как разновидность насилия. Школьный буллинг. Vedecky prumysl evropskeho kontinentu - 2008 : materialy IV Mezinarodni vedecko-prakticka konference. Praha, 2008. C. 75-78. URL: http://www.rusnauka.com/33_NIEK_2008/ Psihologia/37294.doc.htm (дата звернення: 19.09.2019).

8. Опитувальник OLWEUS для здійснення моніторингу в закладі освіти. URL: https://pntu.edu.ua/uploads/files/0/main/deps/ ps/buling/module3/dodatok-5.pdf (дата звернення: 19.09.2019).

9. Словник української мови: в 11 т. Т. 10 : Т-Ф / ред. тому: А. А. Бурячок, Г. М. Гнатюк. Київ, 1979. 658 с.

10. Словник української мови: в 11 т. Т. 11: Х-Ь / ред. тому : С. Головащук. Київ, 1980. 699 с.

11. Стоп шкільний терор. Особливості цькувань у дитячому віці. Профілактика та протистояння булінгу. URL: http://uire.org. ua/wp-content/uploads/2017/11/Doslidzhennya-buling.pdf (дата звернення: 19.09.2019).

12. Українська психологічна термінологія : словник-довідник / за ред. М. Чепи. Київ : ДП «Інформ.- аналіт. агентство», 2010. $640 \mathrm{c}$.

13. Olweus D. Bullying at school : What we know and what we can do. Malden, MA : Blackwell Publishing, 1993.140 p. URL: https://books.google.com.ua/books?id=0FzljD9paoQC\&printsec=frontcover\&hl=ru\#v=onepage \&q\&f=true (дата звернення: 19.09.2019).

\section{References:}

1. Zakon Ukrainy «Pro vnesennia zmin do deiakykh zakonodavchykh aktiv Ukrainy shchodo protydii bulinhu» [Law of Ukraine «About Amendments to Some Legislative Acts of Ukraine on Countering Bullying?]. (2018, December 18, № 2657-VIII). Verkhovna Rada of Ukraine. Retrieved from https://zakon.rada.gov.ua/laws/show/2657-19 [in Ukrainian]. 
2. Zakon Ukrainy «Pro osvitu» [Law of Ukraine «About Education»]. (2017, September 5, №. 2145-VIII). / Verkhovna Rada of Ukraine. Retrieved from https://zakon.rada.gov.ua/laws/show/2145-19 [in Ukrainian].

3. Rekomendatsii MON Ukrainy dlia zakladiv osvity shchodo zastosuvannia norm Zakonu Ukrainy «Pro vnesennia zmin do deiakykh zakonodavchykh aktiv Ukrainy shchodo protydii bulinhu (tskuvanniu)» [Recommendations of the Ministry of Education and Science of Ukraine for educational institutions on the application of Law of Ukraine «About Amendments to Some Legislative Acts of Ukraine on Countering Bullying»] (2018, December 29, № 1/9-790) Retrieved from https://don.kyivcity.gov.ua/files/ 2019/2/14/buling.pdf [in Ukrainian].

4. Metodychni rekomendatsii shchodo zapobihannia ta protydii nasylstvu [Guidelines for the prevention and counteraction to violence] (2018, May 18, № 1/11-5480) Retrieved from https://zakon.rada.gov.ua/rada/show/v5480729-18 [in Ukrainian].

5. Berdyshev, Y. S. (2005). Mediko-psikholohicheskie posledstviia zhestokoho obrashcheniia v detskoi srede. Voprosy dyahnostiki $i$ profilaktiki [Medical and psychological consequences of child abuse. Diagnostic and prevention issues]. SPb. [in Russian].

6. Bulinh - vazhlyva problema dlia ditei v Ukraini. YuNISEF rozpochynaie kampaniiu proty bulinhu [Bulling is an important problem for children in Ukraine. UNICEF launches anti-bullying campaign]. Pedahohichnyi portal: osvitnia presa. Retrieved from http://pedpresa.ua/185372-buling-vazhlyva-problema-dlya-ditej-v-ukrayini-yunisefrozpochynaye-kampaniyu-protybulingu.html [in Ukrainian].

7. Ozhyiova, E. N. (2008) Bullinh kak raznovidnost nasiliia. Shkolnyi bullinh [Bullying as a form of violence. School bullying]. Materialy IV mezinarodni vedecko-prakticka konference «Vedecky prumysl evropskeho kontinentu» (pp. 75-78). Praha. Retrieved from http://www.rusnauka.com/33_NIEK_2008/Psihologia/37294.doc.htm [in Russian].

8. Opytuvalnyk OLWEUS dlia zdiisnennia monitorynhu v zakladi osvity [OLWEUS Questionnaire for monitoring at an educational institution]. Retrieved from https://pntu.edu.ua/uploads/files/0/main/deps/ps/buling/module3/dodatok-5.pdf [in Ukrainian].

9. Buriachok, A. A. \& Hnatiuk, H. M. (Ed). (1979). Slovnyk ukrainskoi movy [Dictionary of the Ukrainian language]. (Vols. 1-11). Kyiv [in Ukrainian].

10. Holovashchuk, S. I. (Ed). (1980). Slovnyk ukrainskoi movy [Dictionary of the Ukrainian language]. (Vols. 1-11). Kyiv [in Ukrainian].

11. Stop shkilnyi teror. Osoblyvosti tskuvan u dytiachomu vitsi. Profilaktyka ta protystoiannia bulinhu [Stop school terror. Features of harassment in childhood. Prevention and confrontation of bulling]. Retrieved from http://uire.org.ua/wp-content/uploads/2017/11/ Doslidzhennya-buling.pdf [in Ukrainian].

12. Chepa, M.-L. A. (2010) Ukrainska psykholohichna terminolohiia: slovnyk-dovidnyk [Ukrainian Psychological Terminology: Dictionary-Handbook] Kyiv: DP «Inform.- analit. Ahentstvo» [in Ukrainian].

13. Olweus, D. (1993) Bullying at school: What we know and what we can do. Malden, MA: Blackwell Publishing. Retrieved from https://books.google.com.ua/books?id=0FzljD9paoQC\&printsec=frontcover\&hl=ru\#v=onepage \&q\&f=true [in English].

Postoian T. H., Novitska I. V. Research into the state of prevention and counteraction to bullying in the educational institutions: applied aspect

The formation of a safe educational environment in an educational institution is one of the most important conditions for achieving a high level of learning outcomes. The prevalence of violence in educational institutions is confirmed by sociological research and places Ukraine in the top ten in the rating of the number of bullying victims. The legal helplessness of educational recipients, low conflict competence, the unwillingness of educational institutions to publish facts of bullying, renders the existing system for participants' in the educational process rights protection ineffective. The purpose of the article is to present the results of the study of the state of management of prevention and counteraction of bullying system in an educational institution using the example of the Economics and Law College of the International Humanitarian University.

The objective of the study is to determine students' awareness of bullying as a social phenomenon; establish the fact of participation in the bullying, the role of the bullying participant; to determine the state of social and legal system of protection, prevention of and counteraction to bullying in college. The study identified the most common forms of bullying, i.e. psychological violence: offensive nicknames, gossip, humiliation, and boycott. Bulling is found to occur in different groups regardless of the year of study, most often on the Internet and on the way to or from college.

Students attributed physical weakness, low level of financial well-being, and the student's unattractive appearance to the most characteristic features of violence victims. The insufficient participation of teachers in countering bullying was determined.

Conclusions. The content and forms of work of the college administration on preventing and counteracting bullying are not effective enough and require revision for strengthening responsibility for compliance with the current anti-bullying legislation of Ukraine by all participants in the educational process and creation a safe, bullying-free educational environment.

Key words: educational institution, educational environment, safety, bullying, prevention, counteraction, questioning, findings. 